\title{
Kegiatan Bimbingan Belajar Masyarakat (BBM) dalam Meningkatkan Motivasi Belajar Keagamaan Siswa di Desa Cileunca, Kecamatan Bojong, Purwakarta
}

\author{
Edah Saadah \\ Program studi Pendidikan Agama Islam, STAI DR. KH. EZ. Muttaqien Purwakarta \\ e-mail: edahsaadah83@gmail.com
}

DOI: https://doi.org/10.52593/svs.01.1.04 Naskah diterima: 19 Desember 2020, direvisi: 19 Desember 2020, disetujui: 9 Januari 2021

\section{Abstraksi}

Kata Kunci:

Bimbingan,

Keagamaan, Motivasi

\begin{abstract}
Kegiatan pengabdian ini dilatarbelakangi rendahnya minat belajar keagamaan anak di desa cileunca, bojong untuk belajar keagamaan. Berdasarkan hal tersebut, kegiatan ini bertujuan untuk mengetahui penyebab penurunan motivasi belajar anak dan rendahnya dorongan orangtua. Hasil dari kegiatan ini dilakukan dengan memberikan pemahaman kepada masyarakat tentang pentingnya pendidikan keagamaan dan menerapkan nilai-nilai keagamaan dalam kehidupan sehari-hari, selain itu membuat bimbingan belajar keagamaan dengan anak-anak usia SD, dan melakukan pengabdian mengajar di salah satu Madrasah Diniyah.
\end{abstract}

\section{PENDAHULUAN}

Pendidikan dalam Islam memiliki kedudukan yang tinggi. Hal ini dibuktikan dengan disebutkannya konsep pendidikan dalam Al-Qur'an dan Al-Hadiis berulangkali. Pendidikan hendaknya jangan hanya dituangkan dalam pengetahuan semata-mata kepada anak didik, tetapi harus juga diperhatikan pembinaan moral, sikap dan tingkah laku. Oleh karena itu, dalam setiap pendidikan, pengetahuan harus ada pendidikan moral dan pembinaan kepribadian yang sehat. Pendidikan seperti itu ada dalam pendidikan Islam, Pandangan masyarakat desa terhadap pendidikan Islam yang dapat diperoleh oleh para anak-anak mereka (remaja) hanya diperlukan di bangku sekolah. Padahal pada kenyataannya, pendidikan Islam juga dapat diperoleh di lingkungan masyarakat. Dalam hal ini masyarakat juga berperan dalam memberikan Pendidikan agama terhadap peningkatan kualitas keimanan pada masyarakat .

Adapun masalah yang ditemukan di desa ini adalah menurunnya tingkat pendidikan agama islam, yang disebabkan oleh pengaruh jaman, kurangnya komunikasi aparat desa dengan warga setempat, jarang di adakan sosialisasi tentang keagamaan atau lainnya, sehingga membuat warga-warga tidak merasa dekat dengan aparat atau dengan warga lainnya, yang membuat mereka merasa tidak penting dengan sebuah perkumpulan atau sebuah organisasi. Dilihat dari segi pendidikan pun warga di desa cileunca memang masih dibawah rata-rata, sehingga teknologi dan perkembangan jaman membuat warga merasa berorganisasi atau mengikuti acara rohani kurang lah penting, sebab mereka bias melihat atau memperlajarinya sendiri dirumah dengan menggunakan teknologi yang ada. (Aida Noer Aini, Muhamad Ridwan Effendi, 2021) Peningkatan kualitas keimanan yang dimaksud adalah pemahaman para masaraskat dalam aplikasi moral di warga yang berefek pada kesadaran para remaja tentang pentingnya berakhlak baik (akhlak mahmudah). metode yang dapat diterapkan di masyarakat untuk meningkatkan kualitas keimanan para warga desa cileunca ,seperti:pengadaan 
pengajian,majelis taklim,kajian ilmiah yang diselingi pembinaan keagamaan, dan lain sebagainya.

Ada pepatah bijak yang mengatakan bahwa semakin berilmu dan berperadaban tinggi, maka semakin tentram kehidupan di masyarakat. ${ }^{1}$ Pernyataan tersebut hendakknya menjadi tolok ukur dalam keberhasilan pemahaman konsep PAI dalam pembinaan akhlak remaja sehingga kualitas keimanan mereka dapat meningkat lebih baik. Disamping itu pentingnya pemahaman konsep PAI di masyarakatdesa cileunca secara baik dan benar diharapkan mampu membentengi falsafah para remaja akan munculnya pemahaman jihad yang salah,seperti munculnya aliran sesat sebut saja ahmadiyah,pemahaman islam yang terlalu fanatik seperti kasus Nurdin M Top dan kawan-kawan,dan lain sebagainya. (Effendi, 2020) Kedua contoh fenomena tentang kesalahpahaman mengenai konsep penerapan PAI di masyararakat desa cileunca perlu diadakan kajian kepada para remaja yang masih memiliki mental labil dan mudah terprovokasi.

Tentunya masyarakat memiliki hak dan kewajiban dalam penyelenggaran pendidikan. Adapun kewajibannya adalah memberikan dukungan sumber daya dalam penyelenggaraan pendidikan. Patisipasi masyarakat dalam pendidikan bisa meliputi peran serta perseorangan, kelompok, keluarga, organisasi profesi, pengusaha, dan organisasi kemasyarakatan.maka dari itu peneliti melakuakn obsevasi deskriftif kualitatif melaului wawancara dengan tokoh tokoh masarakat desa cileunca Untuk meningkatkan mengetahui apa makna dari pendidikan agama islam.dan meningkatkan mengetahui penyebab terjadinya penurunan kualitas pendidikan agama islam didesa cileunca serta meningkatkan kualitas pendidikan agama islam didesa cileunca. Dari latar belakang masalah diatas, fokus skelaigus tujuan dari kegiatan ini adalah melakukan pendampingan dalam rangka menumbuhkan kesadaran motivasi anak dan ornagtua serta aparatur pemerintah desa cileunca untuk meningkatkan peran serta belajar di Madrasah DiniyahTakmiiyah.

\section{METODE}

Metode kegiatan ini dilakukan dengan cara wawancara, observasi kepada orang tua, anak, aparatur pemerintah dan tokoh masyarakat dengan harapan mendapatkan data tentang sejauh mana pemahaman serta kesadaran santri terhadap sholat berjamaah. Kemudian penulis melakukan kegiatan sosialisasi guna melakukan tindakan berupa focus group discussion.

\section{HASIL DAN PEMBAHASAN}

\section{A. Hasil Kegiatan}

Selama kegiatan pengabdian berbasis penelitian yang berlangsung selama satu bulan ini peneliati melakukan beberapa kegitaqn dan menemukan permasalahan mengenai menurunnya kesadaran belajar pendidikan islam di Desa CiLeunca di mulai dengan melakukan wawancara kepada kepla desa cileunca bahwasanya didesa cileunca untuk saat ini desa cileunca mengalami penurunan dalam pendidikan Agama Islam yang di sebabkan oleh minimnya tenaga pengajar PAI di desa cileunca. ${ }^{2}$

Namun hasil wawancara yang di dapat dengan tokoh masyarakat menurutnya peran masyarakat dalam pendidikan agama islam terjadiperubahan dalam tingkat minat belajar

\footnotetext{
1 Wawancara langsung dengan bpk.Ejen junaedi.spd. tokoh masarakat desa pada hari selasa 2 november 2020 pkl.17.00.wib

2 Wawncara kepala desa pada hari kamis tgl 26 desember 2020
} 
tentang pendidikan agama islam singkatnya tempat belajar banyak tetapi tingkat kehadiran nya tidak maksial. ${ }^{3}$ Sealin itu hasil dari wawawnacara dengan tokoh agma. ${ }^{4}$ Bahawasanya peran masarakat dalam meningktakan pendidikan agama islam memang sangat harus ditingkatn lagi karana kurangnya respon dari masarakat stempat.

Masaraakt desa cileunca sudah memamaknai apa pendidikan agama islam dengan cara mengikuti kajian kajian agam islam didesa tersebut,serta masarkat setempat Megalami peningkatan kualitas pendidikan agama islam di desa cileunca. Masyarakat sudah muali memahiami pentingnya pendidikan agama Islam bahkan peran masarakat dalam meningkatkan pendidikan agama islam itu harus ada kolaborasai anatara masarakat setempat denagan kelompok lainnya seperti aparatur setmpat agar terrealisasinya pendidikan agama islam denagan baik.

Gambar 1. Bimbingan bersama masyarakat dan pelajar
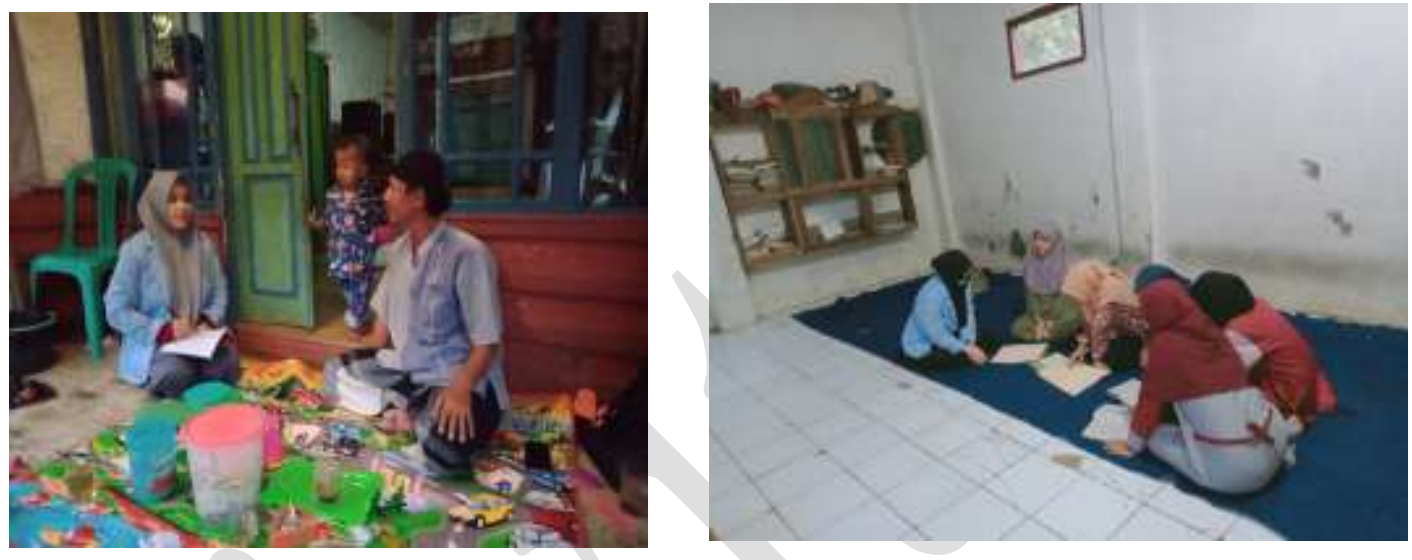

\section{B. Pembahasan}

Menurut masyarakat setempat, pendidikan agama islam didesa cileuna saangat rendah dikaranakan kurangnya peran masyarakat dalam meningkatakan pendidikan agma islam di desa cileunca. Maka dari itu penulis tergerak untuk meningkatkan kualitas pendidikan agama islam didesa cileunca .karana dalam hal pendidikan agama islam didesa cileunca sanagt menuruan jauh berbeda dengan pada tahun tahun sebelimnya. Apalagi disaat setelah melakuakn penelitian PBP ini maka sangat seamakin jelas seakli bahwa penurunan pendidikan agam islam sangat drastic sekali.

Dalam konteks islam, istilah pendidikan mengacu kepada makna da nasal kata yang membentuk kata itu sendiri dalam hubungan nya dengan ajaran islam. Maka konteks ini perlu juga dikaji hakikat pendidikan Islam yang didasarkan pada sejumlah istilah yang umum dikenal dan digunakan para ahli pendidika Islam.

Dari pengertian yang diungkapkan para ahli di atas secara umum dapat di kelompokan menjadi 2 yaitu: (1) Pengertian secara sempit yang mengkhususkan pendidikan hanya untuk anak dan hanya dilakukan oleh lembaga atau institudi khusus dalam rangka mengantarkan kepada masalah kedewasaan: dan (2) pengertian secara luas, yang manapendidikan berlaku bagi semua orang dapat dilakukan oleh semua orang bahkan lingkungan. Tetapi, dari

\footnotetext{
${ }^{3}$ Wawancara dengan tokooh masyarakat bpk.Ejen junaedi 23 oktober 2020

${ }^{4}$ Wawancara dengan Ustd.Aip syarif hidayatulloh pada hari minggu tgl 28 oktober 2020
} 
perbedaan tersebut juga ada kesamaan tujuan "yaitu untuk mencapai kebahagiaan dan nilai yang tinggi. ${ }^{5}$

Setelah peneliti melakuakn penelitian deskriftif kualaitatif dengan mewawancarai beberapaa tokoh masraakt makaa Masarakat desa cileaunca sudaha mulai memahami makna pendidikan agama islam di desa cileunca ,dan terjadinya peningkatan kualitas pendidikan agama islam di desa cileunca,serta cara masyarakat desa cileunca guna meningkatkan kualitas pendidikan agama islam. Dari hasil wawancara yang dilakukan secara langsung di masyarakat peneliti menemukan beberapa kendala selama kegiatan proses pembelajaran agama islam diantaranya adalah 1) Masyarakat Ketika diberi materi tentang pembelajaran agama islam terkesan ramai dan kurang aktif dalam berpendapat ; dan kedua pada proses penelitian masyarakat Tidak semua masyarakat memahami penulis selaku peneliti membuat konsep rutinitas pengajin ibu ibu dan anak anak di majlis talim daruttawabin yang mana kegiatan ini menjadi sebuah rutinitas untuk dilaksanakan masyarakat desa cileunca seiring dengan waktu hari demi hari masyarakat desa cileunca sangat antusias untuk mengikuti kajian tentang pendidikan agama islam. Konsep ini agar warga tersebut terbiasa dengan kegiatan-kegiatan yang berkaitan dengan keagamaan dan mudah untuk masyarakat bersosialisasi dengan warga lainnya dan memudahkan untuk menjalin ikatan kerjasama juga saling gotong royong dalam hal lainnya .

\section{KESIMPULAN}

Peran masyarakat dalam meningkatkan Pendidikan Agama Islam dan lingkungan sangat berpengaruh sekali terhadap pendidikan Agama Islam dengan ditunjangnya para Tokoh setemapat seperti yang sudah saya paparkan diatas. Bahwasnya kita sebagai makhluk yg sempurna wajib mendalami atau memperkuat akan agama, apalagi kita seabgai umat muslim yang mana kita sangat diwajibkan sekali untuk belajar atau memperkuat keagamaan kita lebih dalam lagi dalam hal keagamaan untuk meperkuat keimanan kita kepada Allah.swt.

Desa cileunca adalah seabuah desa kecil yang jauh dari kata ramai kota metropolitan ,sehingga dalam aspek pendidikan islam nya pun sangat menurun sekali. Namun, dengan setelah peneliti melakukan penelitian ini Alhamdulilah sudah mulai kegiatan rutinitas tentang keagamaan seperti dengan adanya kajian kajian islam didesa cileunca salah satunya rutinitas pengajian sore dan siang untuk ibu ibu, begitupun seabliknya pengajian anak anak yang sudah mulai menjadi suatu rutinitas

Menurunnya pendidikan agama islam di desa cileunca faktornya adalah kurangnya peranan masarakat desa cileunca dalam mengaktifknnya kegiatan kegiatan ke agamaman sehingga berimabs juga terhadap warga masarakat setempat mengadakan rutini tas pengajian pengajian di hari tertenu yang mna pada hari tertentu untuk ibu" dan remaja remaja setempat.

\footnotetext{
${ }^{5}$ Anonim. $(2020,11$ 15). peranan masyarakat dalam meningkatkan pendidikan agama islam. Retrieved from pokjawaspaibogor: https://jorjoran-wordpresscom.cdn.ampproject.org/v/s/jorjoran.wordpress.com/2011/04/06/peranan-masyarakat-dalammeningkatkan-pendidikan-agamamakalah/amp/?usqp=mq331AQSKAFQApgB397aqdnuwMlpsAEg\&amp_js_v=a6\&amp_gsa=1\#aoh= $16063789825462 \&$ referrer=https $\% 3 \mathrm{~A} \% 2 \mathrm{~F}$
} 


\section{DAFTAR PUSTAKA}

Anonim. (2020, 11 15). peranan masyarakat dalam meningkatkan pendidikan agama islam. Retrieved from pokjawaspaibogor: https://jorjoran-wordpress-com.cd

Aida Noer Aini, Muhamad Ridwan Effendi, E. N. (2021). Strategi Menanamkan Nilai - Nilai Akhlak Melalui Integrasi Pendidikan. Paedagogie, 2(34-47). https://doi.org/doi.org/10.20211/pdg.02.1.04

Effendi, M. R. (2020). Mitigasi Intoleransi dan Radikalisme Beragama di Pondok Pesantren Melalui Pendekatan Pembelajaran Inklusif. Paedagogie, I(I), 55-74. https://doi.org/doi.org/10.20211/pdg.01.1.05

Effendi, M. R. (2020). Mitigasi Intoleransi dan Radikalisme Beragama di Pondok Pesantren Melalui Pendekatan Pembelajaran Inklusif. Paedagogiel Jurnal Pendidikan dan Studi Islam, 1(1), 56-75.

Effendi, M. R., Barnansyah, R. M., \& Nurpratiwi, S. (2019). MODEL PENDIDIKAN PONDOK PESANTREN INKLUSIF. PROCEEDING BOOK.

http://www.definisi-pengertian.com/2016/02/pengertian-agama-definisi-menurutahli.html?m=1 Diakses Pada Tanggal 03 Desember 2020

https://fitwiethayalisyi.wordpress.com/teknologi-pendidikan/metode-penelitiankualitaif-sistematika-penelitian-kualitatif/Diakses Pada Tanggal 03 Desember 2020

https://fitwiethayalisyi.wordpress.com/teknologi-pendidikan/metode-penelitian-kualitaif10 sistematika-penelitian-kualitatif/ Diakses Pada Tanggal 03 Desember 2020 https://www.konsistensi.com/2013/04/pengumpulan-data-penelitiandengan_13.html?m= Diakses Pada Tanggal 03 Desember 2020 